\title{
HUBUNGAN ANTARA STATUS INVASI MIOMETRIUM DENGAN EKSPRESI CLAUDIN-4 DAN MATRIX METALLOPROTEINASE-2 PADA KARSINOMA ENDOMETRIOID ENDOMETRIUM
}

\author{
Neviana Fitri Lestari* ${ }^{凶}$, Endang Joewarini*, Alphania Rahniayu*
}

\begin{abstract}
Abstrak
Karsinoma endometrium merupakan keganasan terbanyak kelima pada organ reproduksi wanita dengan jenis subtipe terbanyak adalah tipe endometrioid. Salah satu parameter penentuan stadium adalah kedalaman invasi miometrium yang menentukan peningkatan agresifitas dan progresifitas tumor yang berhubungan dengan luas tindakan operasi. Protein claudin-4 dan matrix metalloproteinase-2 (MMP-2) adalah protein penentu dalam invasi karsinoma. Penelitian ini bertujuan mengungkap peran claudin-4 dan MMP-2 dalam invasi myometrium karsinoma endometrioid endometrium. Penelitian ini merupakan penelitian analitik observasional dengan pendekatan cross sectional menggunakan sampel 44 blok parafin sampel karsinoma endometrioid endometrium di RSUD Dr. Soetomo periode 1 Januari-31 Desember 2017. Sampel dibagi menjadi kelompok status invasi kurang dan lebih dari separuh tebal miometrium. Pulasan imununohistokimia menggunakan antibodi monoklonal claudin-4 dan MMP-2, ekspresi dinilai berdasarkan nilai scoring semikuantitatif. Hubungan berbagai variabel dianalisis menggunakan tes korelasi Spearman rho. Hasil penelitian menunjukkan hubungan yang bermakna antara status invasi miometrium dengan ekspresi claudin-4 $(p=0,005)$. Tidak didapatkan hubungan yang bermakna antara status invasi miometrium dengan ekspresi MMP-2 $(p=0,549)$. Didapatkan hubungan yang bermakna antara ekspresi claudin-4 dengan ekspresi MMP-2 $(p=0,001)$. Kesimpulan dari penelitian ini adalah ekspresi claudin-4 berhubungan dengan status invasi miometrium karsinoma endometrioid endometrium, ekspresi MMP-2 tidak berhubungan dengan status invasi miometrium karsinoma endometrioid endometrium serta terdapat hubungan bermakna antara ekspresi claudin-4 dan MMP-2 pada karsinoma endometrioid endometrium.
\end{abstract}

Kata kunci: claudin-4, karsinoma endometrioid endometrium, MMP-2.

\section{CORRELATION BETWEEN MYOMETRIAL INVASION STATUS WITH CLAUDIN-4 AND MATRIX METALLOPROTEINASE-2 EXSPRESSION IN ENDOMETRIOID CARCINOMA OF ENDOMETRIUM}

\begin{abstract}
Endometrial carcinoma is the fifth most frequent type of malignancy found in the female reproductive system, and the most common subtype is endometrioid. Myometrial invasion is one of the staging parameters used to determine tumor aggresivity and progressivity that influence the surgery extention. Claudin-4 and matrix metalloproteinase-2 (MMP-2) proteins determine the growth and invasion of the carcinoma. Analysis of claudin-4 and MMP-2 expression was conducted to reveal their roles in myometrial invasion of the endometrioid endometrial carcinoma. An analytical observational study was conducted on 44 parrafin blocks of endometrioid endometrial carcinoma at Dr. Soetomo Hospital Surabaya during 1 January31 December 2017. Samples were divided into 2 groups, less and more than half of the myometrial depth. Immunohistochemistry staining was performed to detect claudin-4 and MMP-2 expression. Data was statistically analysed using Spearman rho correlation test. The result showed there were significant correlation between myometrial invasion status with claudin-4 expression $(p=0.005)$, there were no significant correlation between myometrial invasion status with MMP-2 $(p=0.549)$. There were significant correlation between claudin-4 with MMP-2 expression $(p=0.001$ ). This study concludes claudin- 4 significantly correlates with myometrial invasion status, MMP-2 does not correlate with myometrial invasion status, and claudin-4 expression significantly correlates with MMP-2 expression in endometrioid endometrial carcinoma.
\end{abstract}

Keywords: claudin-4, endometrioid endometrial carcinoma, MMP-2.

* Departemen Patologi Anatomi, Fakultas Kedokteran, Universitas Airlangga, Surabaya.

E-mail:nevianaf|@gmail.com 


\section{Pendahuluan}

Karsinoma endometrium adalah keganasan yang menduduki peringkat kelima terbanyak pada wanita di seluruh dunia. Kasus baru karsinoma endometrium yang didiagnosis setiap tahunnya berrjumlah sekitar 319,605 kasus di dunia. ${ }^{1}$ Data dari International Agency for Research on Cancer tahun 2018 menunjukkan bahwa kasus baru karsinoma endometrium di Indonesia diperkirakan sejumlah 6.745 kasus dengan jumlah kematian 2407 kasus per tahun. ${ }^{2}$ Angka kejadian tumor ganas endometrium ini meningkat berdasarkan usia, terbanyak pada wanita post menopause dengan usia rata-rata sekitar 63 tahun. Karsinoma endometrium bisa juga didapatkan pada wanita premenopause terutama yang mengalami hiperestrogenisme. ${ }^{3}$

Status (kedalaman) invasi miometrium adalah indikator prognostik pada karsinoma endometrium. Status invasi miometrium merupakan prediktor independen untuk penyebaran tumor secara hematogen dan penting untuk menentukan terapi adjuvant. Status invasi miometrium diperlukan untuk staging, menentukan prognostik dan terapi adjuvant. ${ }^{4}$ Sorbe membuat klasifikasi risiko preoperasi. Tujuan dari klasifikasi ini adalah untuk mengelompokkan pasien yang memerlukan dan yang tidak memerlukan pengambilan nodus limfe. Hasil analisisnya menunjukkan stadium FIGO, kedalaman (status) infiltrasi miometrium, dan ploidy DNA memberikan informasi prediktif terbaik sehubungan dengan risiko rekurensi tumor. ${ }^{5}$

Claudin-4 adalah tight junction (TJ) berupa protein membran tetraspan yang tersusun dari terminal amino dan terminal karboksil, 4 transmembran domain dan 2 ekstra selular loop intrasel. ${ }^{6}$ Claudin-4 diduga merupakan bagian standar pada setiap TJ. Claudin-4 secara fungsional menjaga $\mathrm{TJ}$ dari aliran ion-ion, dan mampu menghalangi pertukaran makromolekul paraselular. ${ }^{7}$
Claudin-4 terekspresi terutama pada membran sel dan peningkatan ekspresinya berkorelasi dengan onset dan perkembangan karsinoma endometrium.

Matrix metalloproteinase (MMP) adalah keluarga endopetidase yang berperan dalam degradasi kolagen dan makromolekul matriks ekstraseluler sehingga memiliki implikasi pada kondisi patologik, termasuk inflamasi, invasi tumor dan metastasis. Telah diketahui bahwa overekspresi proMMP-2 oleh fibroblas di stroma pada jaringan karsinoma ditangkap dan diaktifkan oleh sel karsinoma. Hasilnya aktivitas MMP-2 memicu perbedaan stimulus kemotaktik yang memicu migrasi sel mengarah pada invasi sel tumor. ${ }^{8,9}$

Penelitian ini bertujuan mengetahui hubungan antara status invasi miometrium dengan ekspresi claudin-4 dan MMP-2, serta mencari hubungan antara kedua protein tersebut dengan karsinoma endometrioid endometrium (KEE), sehingga dapat digunakan sebagai marker prognostik.

\section{Bahan dan Metode}

\section{Desain Penelitian}

Penelitian ini merupakan penelitian analitik observasional dengan pendekatan cross sectional menggunakan 44 blok parafin penderita KEE yang didiagnosis di Instalasi Patologi Anatomik Rumah Sakit Dr. Soetomo, Surabaya periode 1 Januari hingga 31 Desember 2017. Penelitian ini telah mendapat persetujuan etik dari Komite Etik Penelitian Kesehatan RSUD Dr. Soetomo dengan nomor surat 0381/KEPKNVII/2018.

Deteksi Ekspresi Claudin-4 dan MMP-2 pada Karsinoma Endometrioid Endometrium dengan Metode Imunohistokimia (IHK)

Sampel terbagi menjadi 2 kelompok yaitu kelompok status invasi kurang dari separuh tebal miometrium dan kelompok status invasi lebih dari separuh tebal miometrium yang ditentukan secara 
makroskopis dan mikroskopis, ${ }^{5}$ masingmasing berjumlah 22 sampel. Kedua kelompok sampel kemudian dipulas dengan pengecatan imununohistokimia (IHK) menggunakan antibodi monoklonal claudin-4, clone sc-376643 (Santa Cruz Biotechnology, Inc.) dengan pengenceran 1:400, dinyatakan positif apabila terpulas pada membran dan sitoplasma sel tumor. Kontrol claudin-4 menggunakan sel karsinoma mamma. Deteksi MMP-2 menggunakan antibodi monoklonal MMP-2 clone sc-13595 (Santa Cruz Biotechnology, Inc.) dengan pengenceran $1: 250$, dinyatakan positif apabila terpulas pada membran sel tumor. Kontrol MMP-2 menggunakan sel urothelial normal. Slide jaringan diperiksa menggunakan mikroskop cahaya binokuler, merek Olympus tipe CX31. Hasil pulasan IHK dinilai secara semikuantitatif dari perkalian intensitas dan persentase atau immunoreactive score (IRS). Penilaian dilakukan pada seluruh lapang pandang dalam 1 slide, dengan skor intensitas yaitu $0=$ no stain; 1 = lemah; 2 = sedang; $3=$ kuat. Skor persentase yaitu $0=$ negatif/tidak terpulas; $+1=$ terpulas pada $<10 \%$ sel tumor; $+2=$ terpulas pada $10 \%$ $50 \%$ sel tumor; $+3=$ terpulas pada $>51 \%$ $80 \%$ sel tumor; $+4=$ terpulas pada $>80 \%$ sel tumor. ${ }^{10}$ Hubungan antara status invasi miometrium dengan ekspresi claudin-4 dan MMP-2, serta hubungan antara kedua protein claudin-4 dan MMP-2 dianalisis dengan uji korelasi Spearman rho.

\section{Hasil}

Ekspresi Claudin-4 pada Karsinoma Endometrioid Endometrium

Karsinoma endometrioid endometrium (KEE) dengan invasi kurang dari separuh tebal miometrium, ekspresi claudin-4 dengan immunoreactive score (IRS) paling banyak adalah skor 1 atau lemah yaitu 10 sampel $(45,5 \%)$ dan pada KEE dengan status invasi miometrium lebih dari separuh tebal, yang terbanyak adalah skor 3 atau kuat yaitu 10 sampel (45,5\%) (Tabel 1). Pada Gambar 1 ditunjukkan ekspresi claudin-4 hasil pulasan IHK.

Hubungan antara status invasi miometrium KEE dengan ekspresi claudin-4 diuji secara statistik dengan uji korelasi Spearman's rho, mendapatkan nilai $p$ sebesar 0,005 yang berarti ada hubungan status invasi miometrium dengan ekspresi claudin-4. Koefisien korelasi sebesar 0,414 yang bernilai positif menunjukkan semakin tinggi ekspresi claudin-4 sejalan dengan peningkatan status invasi.

Tabel 1. Ekspresi claudin-4 pada karsinoma endometrioid endometrium (KEE).

\begin{tabular}{lcccc}
\hline \multirow{2}{*}{ Status Invasi } & \multicolumn{4}{c}{ Skor IRS } \\
\cline { 2 - 5 } & Negatif & Lemah & Sedang & Kuat \\
\hline Kurang dari separuh tebal miometrium & $0(0 \%)$ & $10(45,5 \%)$ & $9(40,9 \%)$ & $3(13,6 \%)$ \\
\hline Lebih dari separuh tebal miometrium & $1(2,56 \%)$ & $8(20,51 \%)$ & $9(23,07 \%)$ & $18(46,1 \%)$ \\
\hline
\end{tabular}

Tabel 2. Hasil uji Spearman's rho pada ekspresi claudin-4.

\begin{tabular}{cclcc}
\hline & & Status invasi & Claudin-4 \\
\hline Spearman's rho & Status invasi & Correlation Coefficient & 1.000 & .414 \\
& & Sig. (2-tailed) & & .005 \\
\hline & $\mathrm{N}$ & 44 & 44 \\
\hline & & .414 & 1.000 \\
\hline & Claudin-4 & .005 & \\
\hline & Sig. (2-tailed) & 44 & 44 \\
\hline
\end{tabular}



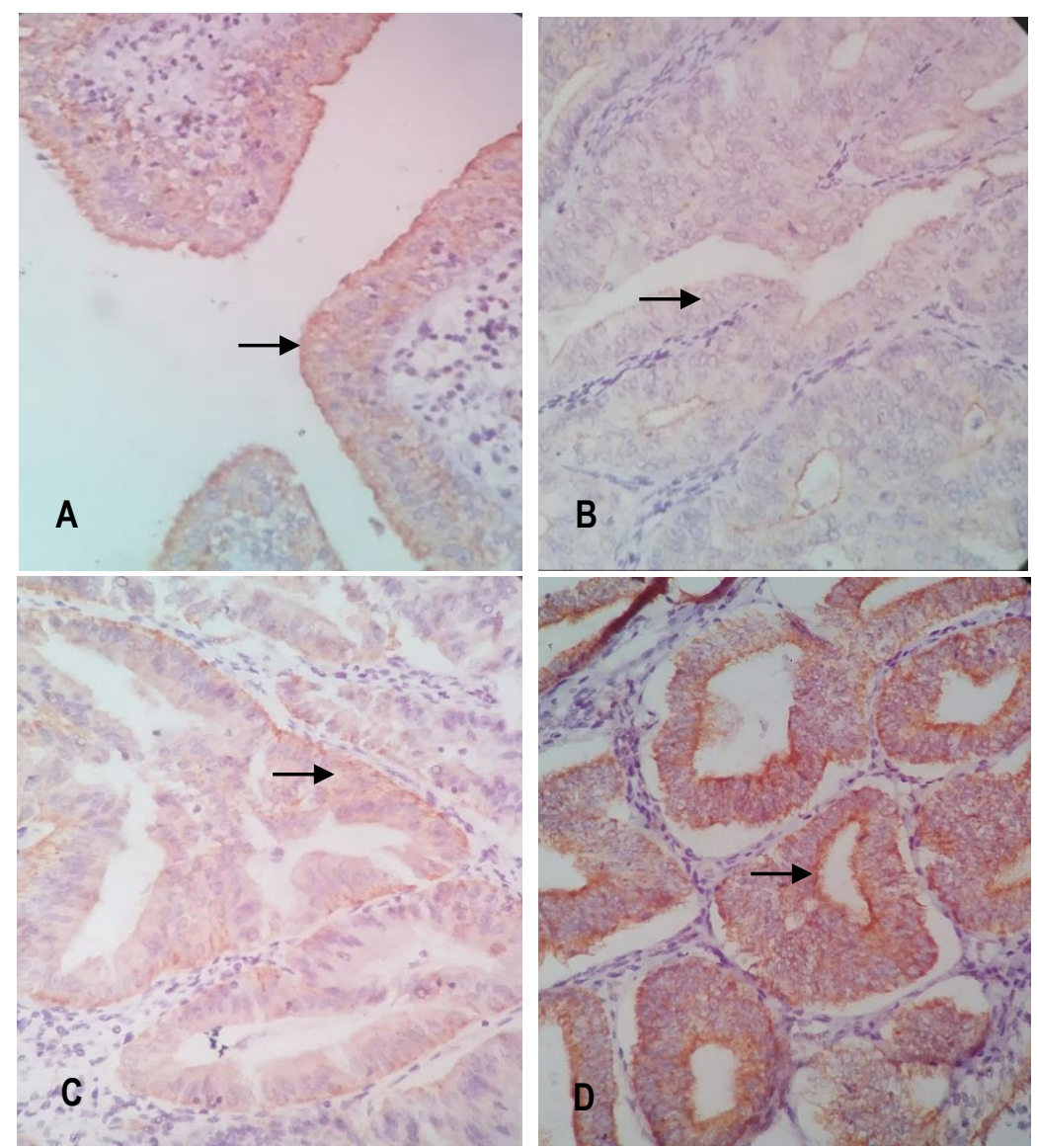

Gambar 1. Ekspresi claudin-4 (tanda panah) hasil pulasan IHK pada karsinoma endometrioid endometrium (400x).

Keterangan: A. Kontrol, B. Ekspresi claudin-4 lemah (skor 1), C. Ekspresi claudin-4 sedang (skor 2), dan D. Ekspresi claudin-4 kuat (skor 3).

\section{Ekspresi MMP-2 pada Karsinoma} Endometrioid Endometrium

Karsinoma endometrioid endometrium (KEE) dengan invasi kurang dari separuh tebal miometrium, ekspresi MMP-2 paling banyak adalah skor 2 atau sedang yaitu sebanyak 12 sampel $(54,5 \%)$, dan pada KEE dengan invasi miometrium lebih dari separuh tebal, yang terbanyak adalah skor 2 atau sedang yaitu sebanyak 9 sampel $(40,9 \%)$. Pada Gambar 2 ditunjukkan ekspresi MMP-2 hasil pulasan IHK.

Hubungan antara status invasi miometrium KEE dengan ekspresi MMP-2 diuji secara statistik dengan uji korelasi
Spearman's rho, mendapatkan nilai $p$ sebesar 0,549 , artinya tidak ada hubungan status invasi miometrium dengan ekspresi MMP-2.

Hubungan antara Ekspresi Claudin-4 dengan Ekspresi MMP-2 pada Karsinoma Endometrioid Endometrium

Hubungan ekspresi claudin-4 dan MMP2 pada karsinoma endometrioid endometrium dengan invasi kurang dari dan lebih dari separuh tebal miometrium diuji secara statistik dengan uji korelasi Spearman rho. Hasil uji Spearman rho (Tabel 5) mendapatkan nilai $p$ sebesar 0,001 , artinya ada hubungan ekspresi claudin-4 dengan MMP-2, pada total sampel kedua kelompok 
invasi kurang dan invasi lebih dari separuh tebal miometrium. Koefisien korelasi sebesar 0,493 yang bernilai positif menunjukkan semakin tinggi ekspresi claudin-4, maka ekspresi MMP-2 juga semakin tinggi.

Tabel 3. Ekspresi MMP-2 pada karsinoma endometrioid endometrium (KEE).

\begin{tabular}{lcccc}
\hline \multirow{2}{*}{ Status Invasi } & \multicolumn{4}{c}{ Skor IRS } \\
\cline { 2 - 5 } & Negatif & Lemah & Sedang & Kuat \\
\hline Kurang dari separuh tebal miometrium & $0(0 \%)$ & $6(27,3 \%)$ & $12(54,5 \%)$ & $4(18,2 \%)$ \\
\hline Lebih dari separuh tebal miometrium & $0(0 \%)$ & $6(27,3 \%)$ & $9(23,07 \%)$ & $7(31,8 \%)$ \\
\hline
\end{tabular}

Tabel 4. Uji statistik Spearman's rho ekspresi MMP-2.

\begin{tabular}{cclcc}
\hline & & Status invasi & Claudin-4 \\
\hline Spearman's rho & Status invasi & Correlation Coefficient & 1.000 & .093 \\
\hline & & Sig. (2-tailed) & & .549 \\
\hline & $\mathrm{N}$ & 44 & 44 \\
\hline & Correlation Coefficient & .093 & 1.000 \\
\hline & Slaudin-4. (2-tailed) & .549 & \\
\hline & $\mathrm{N}$ & 44 & 44
\end{tabular}
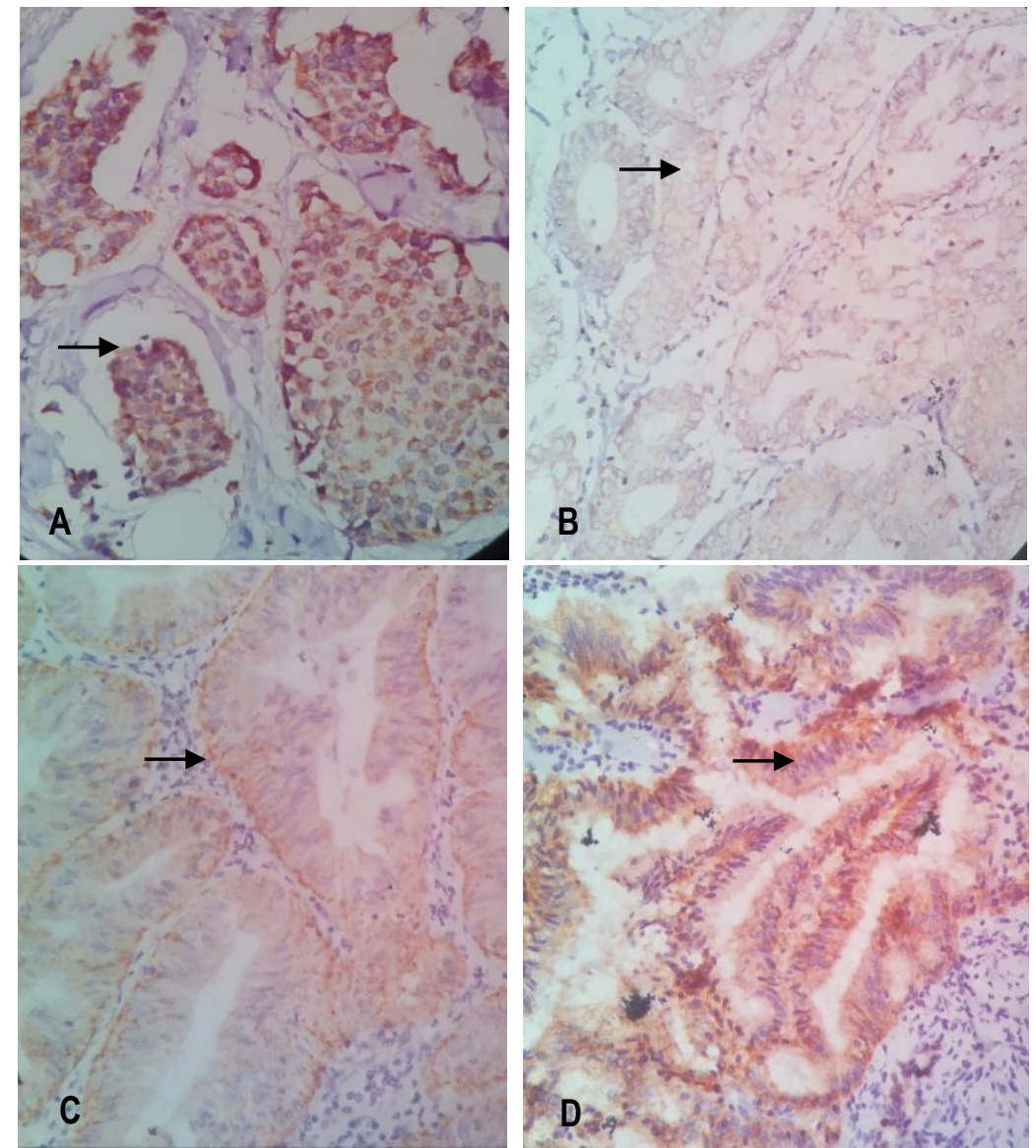

Gambar 2. Ekspresi MMP-2 (tanda panah) hasil pulasan IHK pada karsinoma endometrioid endometrium (400x).

Keterangan: A. Kontrol, B. Ekspresi MMP-2 lemah (skor 1), C. Ekspresi MMP-2 sedang (skor 2), dan D. Ekspresi MMP-2 kuat (skor 3). 
Tabel 5. Uji statistik Spearman's rho ekspresi claudin-4 dan MMP-2.

\begin{tabular}{cclcc}
\hline & & Claudin-4 & MMP-2 \\
\hline Spearman's rho & Status invasi & Correlation Coefficient & 1.000 & .493 \\
\cline { 3 - 4 } & & Sig. (2-tailed) & & .001 \\
\hline & $\mathrm{N}$ & 44 & 44 \\
\hline & & .493 & 1.000 \\
\hline & Claudin-4 & Correlation Coefficient & .001 & \\
\hline & Sig. (2-tailed) & 44 & 44 \\
\hline
\end{tabular}

\section{Pembahasan}

Hubungan antara Status Invasi Miometrium dengan Ekspresi Claudin-4 Karsinoma Endometrioid Endometrium (KEE)

Hasil penelitian ini menunjukkan adanya hubungan antara ekspresi claudin-4 dengan status invasi miometrium pada total sampel kedua kelompok status invasi kurang dan lebih dari separuh tebal miometrium karsinoma endometrioid endometrium, semakin tinggi ekspresi claudin-4, maka akan meningkat status invasi.

Hal ini sejalan dengan penelitian Pan dkk., di Department of Gynecology, Qi Lu Hospital of Shan Dong University dan the Affiliated Hospital of Qing Dao University Medical School, pada Juli 2005 hingga November 2005. Sampel berusia 19 hingga 68 tahun. Penelitian Pan mengamati ekspresi claudin-4 pada endometrium normal, hiperplasia tanpa atipia dan dengan atipia serta karsinoma endometrioid endometrium. Adanya peningkatan ekspresi claudin-4 pada jaringan karsinoma dibandingkan jaringan endometrium normal. Peningkatan ekspresi claudin-4 pada sel karsinoma ovarium mengarah pada pertumbuhan dan metastasis kanker. Hasil ini paradoks dengan hasil penelitian pada cell line pankreas yang memperlihatkan ekspresi claudin-4 mengarah pada penurunan invasi, dan penurunan potensi metastasis. Alasan dari perbedaan ini kemungkinan adalah fungsi yang bersifat spesifik jaringan dan mungkin tergantung pada sirkuit molekular tertentu. Kesimpulan penelitian Pan bahwa ekspresi claudin-4 yang terus-menerus mungkin diperlukan dalam perkembangan karsinoma endometrium. Pan menemukan bahwa terdapat kecenderungan peningkatan ekspresi claudin-4 sejalan dengan grade dan stadium, walaupun secara statistik tidak signifikan. Hasil statistik juga menunjukkan bahwa ekspresi claudin-4 yang tinggi berhubungan dengan invasi miometrium. Membran sel kanker bagian lateral tersusun kurang padat dan tampak bergelombang. Morfologi tight junction mengalami kerusakan dan peluruhan. ${ }^{11}$

Penelitian oleh Agarwal, D'Souza dan Morin (2005) mengkonfirmasi peran claudin-4 pada tumorigenesis ovarium. Mereka menggunakan sel human ovarian surface epithelial (HOSE) yang mengandung claudin4 wild-type. Ekspresi claudin-4 pada sel HOSE meningkatkan invasi dan motilitas sel, fenomena ini diamati dengan boyden chamber assays dan eksperimen proses penyembuhan luka (wound-healing experiments). Perubahan morfologik sel tampak dan diduga berkaitan dengan peningkatan ekspresi claudin-4. Sel tumor yang mengekspresikan claudin-4 memiliki morfologi yang lebih fibroblastik, dengan bentuk yang iregular dan memanjang. Selain itu, sel epitel ovarium yang mengekspresikan claudin-4 memiliki aktivitas matrix metalloproteinase-2 (MMP-2) yang meningkat. Hal ini mengindikasikan bahwa invasi yang dimediasi oleh claudin mungkin difasilitasi melalui aktivasi protein MMP. ${ }^{12}$

Peran claudin-4 dalam perkembangan tumor diduga terletak pada perannya pada migrasi, invasi dan metastasis sel kanker, yang bersifat spesifik-jaringan. Studi terakhir 
memperlihatkan bahwa claudin berperan pada epithelial to mesenchymal transition (EMT), pembentukan cancer stem cells atau tumor-initiating cells (CSCs/TICs), dan kemoresistensi. Disregulasi ekspresi claudin4 terjadi pada level transkripsional dan level post-transkripsional. Sejumlah bukti mengindikasikan bahwa mekanisme epigenetik antara lain metilasi DNA, modifikasi histon atau microRNAs (miRNAs) penting untuk pengaturan ekspresi claudin. Claudin dapat berperan sebagai cancerpromoting atau tumor suppressor. ${ }^{13}$

Ekspresi claudin-4 yang meningkat atau menurun diatur oleh fosforilasi melalui kinase. Contohnya adalah fosforilasi claudin-4 oleh protein kinase $\mathrm{A}(\mathrm{PKA})$ atau protein kinase $\mathrm{C}$ (PKC) meningkatkan permeabilitas paraselular pada sel karsinoma ovarium, dengan cara perpindahan lokasi claudin. Perpindahan lokasi claudin-4 memicu penurunan kekuatan barrier tight junction yang mengarah pada invasi tumor. 13,14 Agarwal dkk., menemukan bahwa $\mathrm{C}$ terminus pada claudin-3 merupakan substrat yang baik untuk protein kinase cAMP-dependent pada threonin 192. Overekspresi protein yang memiliki mutasi T192D, menyerupai keadaan fosforilasi, mengarah pada penurunan kekuatan tight junction cell line karsinoma ovarium OVCA433. Hal ini mungkin merupakan mekanisme perusakan tight junction pada karsinoma. ${ }^{12}$

Ekspresi claudin-4 yang meningkat pada karsinoma ovarium dihubungkan dengan hipometilasi DNA, sedangkan amplifikasi gen tidak berhubungan dengand ekspresi claudin4. Selain metilasi DNA, penelitian Kwon melaporkan bahwa hilangnya histon represif metilasi, termasuk H3K27me3 dan H4K20me3, juga berhubungan dengan ekspresi claudin-3 dan claudin-4 yang tinggi pada karsinoma ovarium. Penelitiannya pada karsinoma ovarium menunjukkan bahwa derepressi epigenetik selain juga inaktivasi epigenetik dari gen supresor tumor, mungkin merupakan suatu mekanisme pada aktivasi gen cancer-associated. Penelitian terdahulu menunjukkan bahwa faktor transkripsi dan modifikasi epigenetik berperan dalam pengaturan transkripsional level claudin. Faktor trasnkripsi Sp1 penting untuk aktivitas promoter CLDN3 dan CLDN4, dan status epigenetik termasuk metilasi DNA dan asetilasi histon $\mathrm{H} 3$, pada region yang mengandung binding site Sp1 juga memiliki peran dalam regulasi ekspresi CLDN3 dan CLDN4 pada sel karsinoma ovarium. ${ }^{13}$

Evaluasi invasi miometrium pada jaringan histerektomi dihubungkan dengan insiden metastasis kelenjar getah bening, yang diharapkan dapat digunakan untuk memprediksi penyebaran tumor. Nenad dkk., meneliti tentang faktor prognostik penyebaran karsinoma endometrium melalui kelenjar getah bening, antara lain status invasi miometrium, ukuran tumor dan invasi limfovaskular. Penelitian yang dilakukan di University Clinic for Gynecology and Obstetrics di Banja Luka, pada periode 2010 hingga 2015 pada 221 jaringan karsinoma endometrium. Karsinoma endometrium risiko rendah yaitu dengan invasi miometrium kurang dari separuh, ukuran tumor kurang dari $2 \mathrm{~cm}$, tidak didapatkan invasi limfovaskular, dan tumor grade I, memiliki tingkat metastasis kelenjar getah bening pelvis yang rendah. ${ }^{15}$

Parameter tersebut penting untuk mengurangi jumlah tindakan limfadenektomi pelvis. Penderita yang memiliki risiko metastasis limfatik yang tinggi, yaitu dengan invasi tumor lebih dari separuh tebal miometrium, ukuran tumor lebih dari $2 \mathrm{~cm}$, invasi limfovaskular, tumor grade 2 dan grade 3 , didapatkan tingkat metastasis kelenjar getah bening pelvis yang tinggi, sehingga memerlukan tindakan limfadenektomi pelvis dan paraaorta. Tindakan ini bisa menurunkan tingkat kematian lebih dari $50 \%$ dan meningkatkan masa survival 5 tahun. ${ }^{15}$ 
Sebagian besar karsinoma endometrium menyebar melalui jalur limfogen. Dua puluh lima persen dari tumor grade 3 bermetastasis melalui limfe. Invasi tumor pada $2 / 3$ tebal miometrium dihubungkan dengan $22 \%$ kasus penyebaran limfogen dan $15 \%$ bila tampak invasi sel tumor dalam pembuluh darah. Dua per tiga pasien dengan metastasis limfogen hanya mengenai kelenjar getah bening pelvis, tetapi juga bisa mengenai lebih dari 10\% kelenjar getah bening paraaorta. Terapi yang direkomendasikan untuk karsinoma grade 3 dengan invasi miometrium lebih dari separuh tebal adalah histerektomi dengan adnesektomi dengan limfadenektomi pelvis dan paraaorta. Karsinoma grade 1 atau 2 dengan invasi miometrium yang lebih dangkal, disarankan untuk dilakukan histerektomi dengan bilateral adnexektomi tetapi tanpa limfadenektomi. ${ }^{16}$

Hubungan antara Status Invasi Miometrium dengan Ekspresi MMP-2 pada Karsinoma Endometrioid Endometrium

Hubungan antara ekspresi MMP-2 dengan status invasi kurang dari dan status invasi lebih dari separuh tebal miometrium karsinoma endometrioid endometrium diuji secara statistik dengan uji korelasi Spearman's rho. Hasil uji menunjukkan tidak didapatkan hubungan antara ekspresi MMP-2 dengan status invasi miometrium pada karsinoma endometrioid endometrium.

Hasil penelitian ini sesuai dengan penelitian Aglund, dkk pada 88 orang penderita karsinoma endometrium, dirawat tahun 1988 hingga 1993 di Rumah Sakit Ume, Finlandia. Studi imunohistokimia antibodi MMP-2 menunjukkan bahwa peningkatan ekspresi MMP-2 berhubungan dengan peningkatan grade histologi. MMP-2 tidak berhubungan dengan invasi miometrium maupun invasi vaskular/limfatik. Faktor penentu perilaku invasi adalah aktivasi MMP. Studi in situ zymography menunjukkan bahwa proporsi MMP yang terdeteksi pada jaringan karsinoma endometrium berbentuk aktif, sehingga disimpulkan bahwa MMP yang aktif berhubungan dengan sel tumor..$^{17}$

Hasil penelitian ini juga sesuai dengan hasil penelitian yang dilakukan oleh Nezza dkk., yang melakukan penelitian pada 29 spesimen penderita karsinoma endometrium di Monash Medical Centre dan the Royal Women's Hospital, Melbourne, Australia yang meneliti MMP-2 dan MMP-9. Penderita berumur 45 hingga 88 tahun dengan rata-rata usia 64. Penelitian tersebut menunjukkan bahwa MMP-9 dan MT1-MMP pada sel tumor berhubungan secara signifikan dengan invasi miometrium dan invasi vaskular/limfatik. MMP-2 tidak berhubungan dengan invasi miometrium dan invasi vaskular/limfatik. ${ }^{18}$ MT1-MMP (membranetype MMPs) mengaktifkan pro-MMP-2 dan memecah kolagen tipe I, II, III, gelatine, fibronectin, laminin-1, vitronectin, cartilage proteoglycans, dan fibrillin-1, dan diekspresikan oleh sel epitel. ${ }^{8}$ Pro-MMP-2 yang diekspresikan oleh sel fibroblast pada jaringan karsinoma atau yang diubah dari serum ditangkap dan diaktifkan pada sel karsinoma oleh MT1-MMP. Overekspresi MT1-MMP berhubungan dengan overekspresi MMP-2. TIMP-2 dibutuhkan untuk aktifasi proMMP-2 oleh MT1-MMP. ${ }^{19}$

TIMP-2 adalah anggota dari keluarga TIMP yang dalam proses inhibisi MMP berinteraksi dengan MT1-MMP untuk memfasilitasi pengaktifan pro-MMP2. Fungsi TIMP-2 adalah sebagai inhibitor MMP dan sekaligus juga diperlukan untuk pengaktifan pro-MMP2.20

Hasil penelitian ini mengkonfirmasi penelitian sebelumnya yang meneliti peran prognostik ekspresi MMP-2 dan TIMP-2 pada karsinoma endometrium, yang menunjukkan bahwa ekspresi MMP-2 diketahui berkorelasi dengan prognosis yang buruk dan ekspresi TIMP-2 yang tinggi berhubungan dengan tingkat survival pada karsinoma endometrium. Ekspresi MMP-2 yang kuat dan ekspresi 
TIMP-2 yang lemah terdeteksi pada subkelompok karsinoma endometrium dengan klinis yang agresif, sehingga keduanya mungkin memiliki potensi prognosis. MMP-2 nampak lebih akurat dibandingkan TIMP-2 dalam menentukan prosnosis karsinoma endometrium bila digunakan terpisah. ${ }^{21}$

Penelitian Fan dkk. menunjukkan adanya ekspresi MMP-2 dan TIMP-2 pada karsinoma kandung empedu. Mereka menemukan bahwa MMP-2 berhubungan dengan stadium Nevin. Ekspresinya pada stadium lanjut lebih kuat daripada stadium awal, tetapi tidak berkorelasi dengan status kelenjar getah bening dan level infiltrasi. Hasil ini tampak kontradiktif dengan laporan penelitian terdahulu. Alasan perbedaan ini adalah metode penelitian dan antibodi yang digunakan berbeda, dan adanya efek ganda TIMP-2. TIMP-2 tidak hanya menghambat aktifitas MMP-2, namun juga berperan dalam aktifasi MMP-2 pada permukaan sel. Jika hubungan antara MMP-2 dan TIMP-2 tidak diteliti bersamaan, maka karakteristik invasif tumor tidak bisa jelas terlihat dengan hanya memeriksa MMP-2. Ekspresi TIMP-2 tidak berbeda signifikan pada tumor dengan tipe histologis dan grade yang berbeda. Ekspresi TIMP-2 pada stadium awal lebih tinggi daripada tumor stadium lanjut dan berhubungan dengan level infiltrasi, metastasis lokal kelenjar getah bening dan invasi hepar. Hal ini menunjukkan ada hubungan antara ekspresi TIMP-2 dengan parameter klinikopatologi stadium, invasi dan metastasis kelenjar getah bening untuk penentuan prognosis penderita karsinoma kandung empedu. ${ }^{22}$

Keseimbangan MMPs/TIMPs adalah faktor penting untuk mempertahankan integritas ECM, dan peran MMP pada metastasis tumor tidak bergantung pada konsentrasi absolut MMP pada area lokal, tetapi pada rasio MMPs/TIMPs. Bila TIMP tidak mampu menghambat kerja MMP, maka matriks ekstraseluler akan dihancurkan sehingga terjadilah invasi. Ketika keseimbangan MMPs/TIMPs rusak, akan mengarah pada degradasi ECM. TIMPs mungkin berperan sebagai faktor prognostik invasi dan metastasis. Hasil penelitian Fan dkk, menunjukkan bahwa rasio MMP-2/TIMP2 berhubungan dengan stadium, level infiltrasi dan rekurensi. Rasio MMP-2/TIMP-2 menunjukkan sifat invasi dan metastasis yang lebih akurat pada karsinoma kandung empedu bila dibandingkan dengan ekspresi MMP-2 ataupun TIMP-2 tersendiri. ${ }^{22}$

Penelitian ini tidak menilai ekspresi TIMP-2 sehingga tidak dapat menilai korelasi antara ekspresi MMP-2 dan ekspresi TIMP-2, dan membuktikan pengaruh TIMP-2 yang dapat menghambat peningkatan ekspresi MMP-2.

Hubungan antara Ekspresi Claudin-4 dengan Ekspresi MMP-2 pada Karsinoma Endometrioid Endometrium

Penelitian ini mendapatkan ada hubungan ekspresi claudin-4 dengan ekspresi MMP-2, pada total sampel kedua kelompok invasi kurang dan invasi lebih dari separuh tebal miometrium KEE. Koefisien korelasi sebesar 0,493 yang bernilai positif menunjukkan semakin tinggi ekspresi claudin4, maka ekspresi MMP-2 juga semakin tinggi.

Ekspresi claudin telah lama dihubungkan dengan matrix metalloproteinases (MMPs). MMP adalah zinc-endopeptidases yang diekskresikan untuk mendegradasi matriks ekstrasellular dan meningkatkan motilitas sel, khususnya pada migrasi sel kolektif. Penelitian Agarwal dkk., menemukan bahwa sel line HOSE (Human Ovarian Surface Epithelial) yang mengandung claudin-4 mengekspresikan peningkatan aktifitas MMP-2 dibandingkan sel HOSE yang tidak mengekspresikan claudin-4. Hasilnya menunjukkan bahwa protein claudin4 berperan pada kontrol motilitas dan invasi melalui MMP-2, setidaknya pada tumor 
ovarium. ${ }^{12}$ Takehara dkk., juga menemukan bahwa pada sel Caco-2 yang memiliki overekspresi claudin-4, tampak peningkatan aktifitas MMP-2 dan MMP-9, dibandingkan sel Caco-2 tiruan. Hasil penelitian Takehara dkk., sejalan dengan hasil penelitian Miyamori dkk., yang menemukan bahwa claudin berhubungan dengan MT1-MMP untuk mengaktifkan MMP-2, menandakan bahwa claudin mungkin meningkatkan aktifitas MMP untuk mendegradasi matriks ekstraselular dan memicu motilitas sel. ${ }^{23}$

Webb dkk., meneliti apakah claudin memerlukan protein matriks ekstrasellular khusus untuk memicu motilitas, sel normal dan sel tumor ditumbuhkan dalam media dengan Cell-Tak, suatu matriks non fisiologik derivat dari protein polifenol moluska. Hasilnya menunjukkan bahwa motilitas kedua tipe sel melibatkan interaksi ekstrasellular claudin yang tampak memerlukan matriks kolagen. ${ }^{23}$

Mekanisme sebab dan efek hubungan antara claudin-4 dan MMP-2 pada karsinoma endometrioid endometrium belum banyak diteliti dan diketahui. Agarwal dkk., melakukan penelitian pada cell line ovarium, mereka melakukan knockdown claudin-3 dan claudin-4 yang dimediasi oleh siRNA pada OVCAR-5. Penghambatan ekspresi claudin-3 dan claudin-4 pada sel OVCAR-5 mengurangi kemampuan invasi sel ini secara signifikan. Knockdown claudin-3 dan claudin-4 yang dimediasi siRNA pada sel OVCAR-5 tidak mengarah pada penurunan aktivitas MMP-2 pada sel itu. Hasil ini menunjukkan bahwa sel karsinoma ovarium mungkin memiliki jalur tambahan atau jalur alternatif untuk mengaktifkan MMP-2.12

Oku dkk., melakukan penelitian yang mencari mekanisme hubungan claudin dan MMP. Mereka melakukan penelitian pada cell line karsinoma sel skuamus oral. Ekspresi claudin-1, MMP-2 dan pembelahan rantai \2 $^{2}$ laminin-5 dengan analisis western blot, IHC dan zymografi. Ekspresi MT1-MMP dan
MMP-2 aktif menurun ketika siRNA claudin-1 dimasukkan ke dalam sel, hal ini membuktikan bahwa claudin-1 meningkatkan ekspresi MT1-MMP melalui mekanisme sinyal tertentu. Cell line yang memiliki ekspresi MT1-MMP dan pro-MMP2 yang tinggi bersifat invasif. Pada cell line OSC-4 dengan ekspresi claudin yang tinggi, terdapat tingkat MT1-MMP dan MMP-2 aktif yang tinggi. Aktivitas invasi dihambat oleh masuknya siRNA claudin-1 ke dalam OSC-4. Hal ini menunjukkan bahwa peningkatan aktivitas claudin-1 dimediasi melalui peningkatan ekspresi MT1-MMP dan aktivasi MMP-2. Penelitian sebelumnya menunjukkan bahwa terdapat overekspresi rantai y2 laminin-5 tepi invasi sel karsinoma yang memiliki sejumlah besar bentuk pemecahan rantai $\gamma 2$ laminin-5. Penelitian ini menunjukkan bahwa rantai y2 laminin-5 dipecah oleh MT1-MMP dan MMP-2 aktif, kemudian rantai y2 laminin-5 yang terpecah menempel pada EGFR permukaan sel kanker, sejumlah sitokin dan faktor pertumbuhan, selanjutnya memacu sinyal pengaktifan invasi sel. Aktifitas invasi sel yang tinggi ini dihambat ketika sel diberi antibodi anti MT1-MMP atau inhibitor MMP-2. Kesimpulannya ekspresi MT1-MMP dan MMP-2 aktif dipicu oleh claudin-1, diikuti oleh pemecahan rantai y2 laminin-5. ${ }^{24}$

\section{Kesimpulan}

Terdapat hubungan yang positif antara status invasi miometrium dengan ekspresi claudin-4 pada karsinoma endometrioid endometrium. Tidak terdapat hubungan status invasi miometrium dengan ekspresi MMP-2 pada karsinoma endometrioid endometrium. Terdapat hubungan yang positif antara ekspresi claudin-4 dengan ekspresi MMP-2, pada karsinoma endometrioid endometrium. 


\section{Saran}

Claudin-4 dapat diaplikasikan sebagai alat bantu untuk penentuan prognosis pada karsinoma endometrioid endometrium sediaan kuretase sebelum operasi. Perlu dilakukan penelitian lebih lanjut untuk mengetahui faktor lain yang berperan pada kejadian invasi miometrium karsinoma endometrioid endometrium, seperti TIMP-2 sehingga dapat dijadikan faktor prognosis dan terapi untuk karsinoma endometrioid endometrium.

\section{Daftar Pustaka}

1. Fernandez-Montoli ME, Sabadell J, Martínez-García JM, Contreras Perez NA. Fertility-Sparing Treatment for Atypical Endometrial Hyperplasia and Endometrial Cancer. Cochrane Database of Systematic Reviews . 2018. Issue 8.

2. International Agency for Research on Cancer. GLOBOCAN 2018: Estimated Cancer Incidence, Mortality and Prevalence Worldwide in 2018. Lyon (Fr): IARC Press. 2018. Available from: http://globocan.iarc.frl.

3. Kurman J, Carcangiu L, Herrington $S$, Young $\mathrm{H}$. Tumours of the Uterine Corpu's. In: WHO Classification of Tumours of Female Reproductive Organs. Lyon (Fr): IARC Press. 2014. p. 124-128.

4. Ganesan R, Singh N, McCluggage WG. Standards and Datasets for Reporting Cancers:Dataset for Histological Reporting of Endometrial Cancer. England: The Royal College Of Pathologist. 2014.

5. Sorbe B. Predictive and Prognostic Factors in Definition of Risk Groups in Endometrial Carcinoma. ISRN Obstetrics and Gynecology. 2012; (325790):8.

6. Fan $Y$, Zhang $J$, Yang $H$, Yang $Y$. Expression of MMP-2, TIMP-2 Protein and the Ratio of MMP-2/TIMP-2 in Gallbladder
Carcinoma and Their Significance. World J Gastroenterol. 2002; 8(6):1138-1143.

7. Milatz S, Krug S, Rosenthal R, Gunzel D, Muller D, Schulzke JD, Amasheh S, Frommzke M. Claudin-3 Acts as A Sealing Component of the Tight Junction for lons of Either Charge and Uncharged Solutes. Biochimica et Biophysica ActaBiomembranes. 2010; 1798(11):20482057

8. Amălinei C, Caruntu I, Giusca SE, Balan RA. Matrix Metalloproteinases Involvement in Pathologic Conditions. Romanian Journal of Morphology and Embryology. 2010; 51(2):215-228.

9. Sato $\mathrm{H}$, and Takino $\mathrm{T}$. Coordinate Action of Membrane-Type Matrix Metalloproteinase-1 (MT1-MMP) and MMP-2 Enhances Pericellular Proteolysis and Invasion. Cancer Science. 2010; 101(4):843-847.

10. Fedchenko N, Reifenrath J. Different Approaches for Interpretation and Reporting of Immunohistochemistry Analysis Results in the Bone Tissue-A Review. Diagnostic Pathology. 2014; 9:221.

11. Pan XY,Wang B, Che YC, Weng ZP, Dai $H Y$, Peng W. Expression of Claudin-3 and Claudin-4 in Normal, Hyperplastic, and Malignant Endometrial Tissue. International Journal of Gynecological Cancer. 2007; 17(1):233-241.

12. Agarwal R, D'Souza T, Morin PJ. Claudin3 and Claudin-4 Expression in Ovarian Epithelial Cells Enhances Invasion and is Associated with Increased Matrix Metalloproteinase-2 Activity. Cancer Research. 2005; 65(16):7378-7385.

13. Kwon MJ. Emerging Roles of Claudins in Human Cancer. International Journal of Molecular Sciences. 2013; 14(9):1814818180.

14. Szabó I, Kiss A, Schaff Z, Sobel G. Claudins as Diagnostic and Prognostic Markers in Gynecological Cancer. 
Histology and Histopathology. 2009; 24:1607-1615.

15. Lucic N, Draganovic D, Sibincic S, EcimZlojutro V, Milicevic S. Myometrium Invasion, Tumour Size and Lymphovascular Invasion as A Prognostic Factor in Dissemination of Pelvic Lymphatics at Endometrial Carcinoma. Med Arch. 2017; 71(5): 325329.

16. Mang C, Blrkenmaier A, Cathomas G, Humburg J. Endometrioid Endometrial Adenocarcinoma: An Increase of G3 Cancers?. Arch Gynecol Obstet. 2017; 295(6):1435-1440. DOI 10.1007/s00404017-4370-4

17. Aglund K, Puistola U, Angstrom T, Turpeenniemi-Hujanen T, Zackrisson B, Stendahl U. Gelatinases A and B (MMP2 and MMP-9) in Endometrial Cancer MMP-9 Correlates to the Grade and the Stage. Gynecologic Oncology. 2004; 94(3):699-704.

18. Di Nezza LA, Misajon A, Zhang J, et al. Presence of Active Gelatinases in Endometrial Carcinoma and Correlation of Matrix Metalloproteinase Expression with Increasing Tumor Grade and Invasion. Cancer. 2002; 94:1466-75.

19. Shiomi T, Okada Y. MT1-MMP and MMP-7 in Invasion and Metastasis of
Human Cancers. Cancer Metastasis Review. 2003; 22(2-3):145-152.

20. Honkavuori-toivola M, Santala M, Soini Y. Combination of Strong MMP-2 and Weak TIMP-2 Immunostainings is A Significant Prognostic Factor in Endometrial Carcinoma. Disease Markers. 2013; 35(4):261-266.

21. Honkavuori-Toivola, M. The Prognostic Role of Matrix Metalloproteinase-2 and -9 and Their Tissue Inhibitor-1 and -2 in Endometrial Carcinoma. Thesis. Finland: University of Oulu. 2014.

22. Fan $Y$, Zhang $J$, Yang $H$, Yang $Y$. Expression of MMP-2, TIMP-2 Protein and the Ratio of MMP-2/TIMP-2 in Gallbladder Carcinoma and Their Significance. World J Gastroenterol. 2002; 8(6):1138-1143 .

23. Webb PG, Spillman MA, Baumgartner HK. Claudins Play a Role in Normal and Tumor Cell Motility. BMC Cell Biology. 2013; 14(1):1.

24. Oku N, Sasabe E, Ueta E, Yamamoto T, Osaki T. Tight Junction Protein Claudin-1 Enhances the Invasive Activity of Oral Squamous Cell Carcinoma Cells by Promoting Cleavage of Laminin-5; 2 Chain via Matrix Metalloproteinase (MMP)-2 and Membrane-Type MMP-1. Cancer Research. 2006; 66(10):5251-7. 